\title{
WHOSE DEMOCRACY? HISTORIES OF BRITISH POLITICAL CULTURE BETWEEN THE WARS*
}

\author{
HELEN M C CARTHY \\ Queen Mary, University of London
}

\begin{abstract}
A B ST RACT. This article reviews the current state of historical writing on British political culture in the interwar period, with a particular focus on the character of the democratic society which emerged from the franchise extensions of 1918 and 1928 . It takes as its starting point the influential interpretation advanced by Ross McKibbin in his two most recent books, Classes and cultures (1998) and Parties and people (2010). This holds that Britain's interwar democracy came to be shaped in the image of the anti-socialist middle class, buoyed by the centrist appeal of Baldwinite constitutional Conservatism. Anti-socialism's interwar hegemony, McKibbin further argues, had serious consequences for the progress of social democracy after the Second World War. Whilst this narrative is, in many respects, highly compelling, this review suggests that much recent literature on the period points to a range of alternative interpretative possibilities which offer different answers to McKibbin's core question: what kind of a democracy was Britain between the wars? Drawing on these studies, the review argues that Britain's political culture was rather more 'democratized' during these years than McKibbin allows, before finally identifying some directions for future research.
\end{abstract}

Until relatively recently, historical writing on British politics between the wars was overwhelmingly preoccupied with solving two problems. The first was the problem of understanding the dynamics of class-based political realignment, and especially the means by which Labour came to supplant the Liberals as the major party of the left. The second was the problem of explaining the response of Britain's political elites to the new international order which took shape after the First World War, and especially the growth of fascism across continental Europe. The dominance of these themes is reflected in the titles of Maurice Cowling's two seminal works on the period, The impact of Labour (1971) and The impact of Hitler (1975). In the former, Cowling argued that the years between 1920 and 1924 set the pattern of domestic politics for the rest of the period, with the Conservative party overcoming internal differences in order to

Queen Mary, University of London, London EI 4NS h.mccarthy@qmul.ac.uk

* The author would like to thank Jon Lawrence and two anonymous reviewers for their extremely helpful comments on earlier versions of this review. 
establish itself as a viable force in mass electoral politics and the chief bulwark against socialism. ${ }^{1}$ In the second volume, Cowling showed how domestic political struggle shifted into the terrain of foreign policy in the 1930s, which soon became the key battlefront of partisan warfare. ${ }^{2}$

Cowling's two works remain landmarks in the field, required reading for any student of interwar politics. This is not least because the problems they address are far from settled, even thirty-five or forty years on. Yet the context in which those problems are posed has altered dramatically as a result of discipline-wide conceptual shifts, methodological innovations, and the exploration of neglected archival material. Modern British political history has, like other fields, been indelibly marked by the 'cultural turn' in the last two decades. Pioneered by scholars such as Drohr Wahrman, James Vernon, Jon Lawrence, and Lawrence Black, the 'new' political history, as it has sometimes been dubbed, has shifted the balance of explanation away from social (and especially class-based) structures in favour of representations, or 'discourses', of politics. ${ }^{3}$ Historical meaning came to be encoded in the utterances of politicians, or the symbolism of election rituals, or the organization of public space, all of which were reconceptualized as 'texts' primed for the task of thick description. 4

These approaches were especially influential for study of the nineteenth century, but even here were never hegemonic. Many scholars continued to view the roots of politics as essentially social in nature, or, at the very least, believed that socio-economic change had a legitimate part to play in the task of historical explanation. This is especially true of the field of twentieth-century political history, where the conceptual and methodological contributions of cultural history have been more cautiously and selectively embraced by scholars who remain otherwise wedded to the more conventional approaches of 'high politics' and labour history. 5 One important reason for this is the influential body of work on the period 1918-51 produced by Ross McKibbin over the past

\footnotetext{
${ }^{1}$ Maurice Cowling, The impact of Labour, I920-1924: the beginning of modern British politics (Cambridge, 1971).

${ }^{2}$ Maurice Cowling, The impact of Hitler: British politics and British policy, I933-I940 (Cambridge, 1975).

3 Drohr Wahrman, Imagining the middle class: the political representation of class in Britain, c. I780-I 840 (Cambridge, 1995); James Vernon, Politics and the people: a study in English political culture, c. I815-I867 (Cambridge, 1993); Jon Lawrence, Speaking for the people: party, language and popular politics in England, I867-1914 (Cambridge, 1998); Lawrence Black, The political culture of the left in affluent Britain, I95 I-I964: old Labour, new Britain? (Basingstoke, 2003).

4 For reflections on the 'new' political history, see Dror Wahrman, 'The new political history: a review essay', Social History, 21 (1996), pp. 343-54; Susan Pedersen, 'What is political history now?', in David Cannadine, ed., What is history now? (Basingstoke, 2002), pp. 36-56; and Jon Lawrence and Miles Taylor, 'Introduction: electoral sociology and the historians', in Lawrence and Taylor, eds., Party, state and society: electoral behaviour in Britain since I 820 (Aldershot, 1997), pp. $1-26$.

5 A good example of this mix of 'cultural' history and 'high' politics is Philip Williamson, Stanley Baldwin: Conservative leadership and national values (Cambridge, 1999).
} 
thirty years. ${ }^{6}$ Like Cowling's before him, McKibbin's auvre must be read and absorbed by anyone serious about understanding the political history of early to mid-twentieth-century Britain. ${ }^{7}$ Those who do will encounter a historical sensibility which, while always attentive to the dynamic interplay of personalities, institutions and unpredictable events, understands politics to be rooted deeply in the structures and cultures of wider society. That society, after the franchise extensions of 1918, was indisputably 'democratic', but to whom, McKibbin asks, did that democracy belong?

This is a question which other historians of the interwar period have been increasingly anxious to answer, reframing, as it were, those familiar problems about voter realignment and foreign policy as problems concerning the wider character and consequences of Britain's transition from a limited, propertybased franchise to a mass democracy. What did it mean to live in a democratic society? How was the new mass electorate imagined by the political class and vice versa? How, in particular, were the political identities of new female voters constructed and sustained? Did universal suffrage nurture new forms of political participation and communication? Did it alter how such organizing concepts as 'public opinion', 'citizenship', and 'nationhood' were understood and enacted? The answers produced by a wealth of recent studies are rich and varied. They frequently intersect with or echo elements of the influential interpretation advanced by McKibbin in his 1998 work, Classes and cultures, and its companion volume, Parties and people of 2010, which holds that Britain's democracy between the wars was defined by an electorally unassailable antisocialist coalition, spearheaded by Stanley Baldwin's Conservative party but reaching deep into the associational cultures and discursive norms of civil society. The legacy of anti-socialism's interwar hegemony, McKibbin contends, had serious consequences for post-war social democracy. ${ }^{8}$

As this review aims to show, this reading of Britain's political culture in the age of mass democracy is, in many respects, highly compelling. Yet, as much recent literature on the period demonstrates, it is not the only story that can be told about the character of British society after 1918. Following an extended discussion of Classes and cultures and Parties and people, the review will attempt to

6 Ross McKibbin, The ideologies of class: social relations in Britain, I880-1950 (Oxford, 1990); Classes and cultures: England, I9I8-I95I (Oxford, 1998); Parties and people: England, I9I4-I95I (Oxford, 2010).

7 One tension in McKibbin's work is the discrepancy between the focus on 'England' in Classes and cultures and Parties and people, and the use of 'Britain' to denote the geographical coverage of earlier works, including Ideologies of class. McKibbin makes it clear, however, in the preface to Parties and people, that his interpretation holds good for Scotland and Wales, where politics 'were to an unusual degree in step' with English politics, if not for Northern Ireland (p. vi). It is on this basis - the assumption that generalizations can be made about politics in this period across England, Scotland, and Wales - that this review refers throughout to 'Britain'.

8 A narrative which is largely replicated by David Marquand in his popular history, Britain since I9I8: the strange career of British democracy (London, 2008), which briefly references McKibbin's work in the endnotes. 
draw out the implications for McKibbin's interpretation of these alternative perspectives, before finally suggesting some future directions for the study of Britain's interwar democracy.

\section{I}

In 1918, the Representation of the People Act introduced universal male suffrage to Britain and enfranchised women aged thirty or above who were local electors or married to local electors. With the equalization of the voting age in 1928, Britain's transformation from a limited property-based franchise into a full liberal democracy was effectively complete. 9 As several generations of political historians have agreed, the implications of this transformation were profound, although there is little consensus over exactly how and why. In this early literature, in which Cowling's work occupied a prominent place, the key problems were framed in institutional terms but were founded on one basic and indisputable sociological fact: the existence of a mass electorate in which the working class now formed the majority. Class became the hinge on which historical explanation of the period's politics turned, be it the Liberal party's declining fortunes, Labour's mixed performance at the ballot box, or the Conservative party's impressive tally of electoral victories under conditions of universal suffrage. All accounts of far-reaching political realignment taking place in this period seemingly led back to the working-class electorate and its relationship with the political classes. ${ }^{10}$

Ross McKibbin is a veteran of this debate, having explored the dynamics of Labour politics in his first book, The evolution of the Labour party, I9IO-I924 (London, 1974), before moving beyond an essentially institutional perspective to pen pioneering essays on economic policy under the second Labour government, the 'social psychology' of unemployment in the 1930s, and the sources of interwar Conservative electoral hegemony. These essays, published collectively in The ideologies of class (1990), were indicative forerunners of McKibbin's most substantial work to date, Classes and cultures: England I9 I8I95 I. Published in 1998, the book encompasses a rich exploration of the complex, multifaceted, but nonetheless cohesive class-based communities which emerged from the post-First World War transformation of Britain's economic base and occupational structure; from changing patterns of leisure, consumption, sexuality, and worship; and, above all, from the recasting of social relationships under conditions of formal political equality. Although its intended subtitle, A study of democratic society, was dropped ahead of publication,

9 The 1918 act preserved a few anomalies, such as the business suffrage and the university franchise. D. E. Butler, The electoral system in Britain since I9I8 (Oxford, 1963).

${ }^{10}$ The literature is too large to list here, but key works include: Chris Cook, The age of alignment: electoral politics in Britain, 1922-1929 (London, 1975); Kenneth O. Morgan, Consensus and disunity: the Lloyd George coalition government, I9I 8-I922 (Oxford, 1979); Gillian Peele and Chris Cook, eds., The politics of reappraisal, I9I8-I939 (London, 1975). 
the centrality of this theme to Classes and cultures is obvious from the outset. ${ }^{11}$ 'The English,' McKibbin observes in the preface, 'lived in what nearly all agreed was a democracy. They were not, however, necessarily agreed on what democracy meant or should mean.' ${ }^{12}$

Identifying those conflicting visions of democracy, and-cruciallydiscovering which won out, lies at the heart of McKibbin's inquiry. His verdict is uncompromising: Britain's democracy was decisively shaped after the First World War by the defeat of the organized working class at the hands of an increasingly well-integrated and anti-socialist middle class. This defeat was secured by a depoliticized popular culture and associational habits which obscured the fundamental conflict underpinning social relations between the classes, much to the Conservative party's electoral advantage. By 1939, the middle class had successfully made its own particular definition of democracy come to stand for British democracy in general; individualist, liberal, and selfconsciously 'modern', this definition would be temporarily displaced by an alternative, social-democratic, version associated with the organized working class in the 194 os through the radicalizing effects of total war. Yet the limited, pre-war model was embedded into what McKibbin calls Britain's 'civil cultures' so deeply, its intrusion into the dynamics of social relations was so profound, that post-war Labour governments were unable (or unwilling) to dislodge it, despite introducing large-scale programmes of social welfare and nationalization unimaginable in 1939 .

Classes and cultures offers, then, a highly innovative and suggestive account of Britain's journey from minimalist liberal democracy to something approaching, but never fully achieving, social democracy. McKibbin's much shorter, interpretative work, Parties and people: England I9I4-I95I, reinforces these general conclusions, but spells out concretely the role of electoral politics in giving coherence and ideological force to the cultures of class. Partisan conflict in the 1920s, he argues, was characterized by strong class antagonisms, reflecting the disruptive effects of the First World War on the Lib-Lab 'progressive alliance' and resolving with the eventual polarization of the electorate into two camps: a Conservative coalition that in essence represented the middle class whilst garnering the votes of many who stood outside it (but perhaps wished to join it), and a Labour party that stood for the working class, and especially its organized sections. After the 1931 crisis and its resolution, anti-socialism settled into a more relaxed groove, its hegemony restored. In these years, the Conservative-dominated National Government cultivated a cross-class electoral constituency united by a generalized aversion to 'socialist' politics. Labour meanwhile, with its credibility as a party of government in

11 See Peter Ghosh's detailed critique of McKibbin's work in 'The guv'nor: the place of Ross McKibbin in the writing of British history', in Clare J. Griffiths, James J. Nott, and William Whyte, eds., Classes, cultures and politics: essays on British history for Ross McKibbin (Oxford, 201 1), p. 3 o.

${ }_{12}$ McKibbin, Classes and cultures, p. v. 
tatters, was slow to recover the working-class votes it had first secured in 1929 but lost in 1931 and struggled to discredit the centrist appeal of a Baldwinite brand of moderate constitutional Conservatism.

In Parties and people, 1940 emerges as a crucial turning point, for it was the political and military crisis of May-June of that year which toppled the Conservative party from its seemingly impregnable electoral position. Labour's decision to join Churchill's coalition government following Chamberlain's fall was a game-changing event that paved the way to victory at the ballot-box in 1945. Certainly, the pressures of fighting a total war subsequently shifted the balance of political power in favour of the working class, with an accompanying redistribution of what McKibbin calls 'social esteem'. Other historians (including, indeed, Cowling) have attached equal importance to the events of May 1940 in shaping the subsequent trajectory of Britain's war. McKibbin, however, unlike these earlier accounts, insists that the trigger for this transformation - the political revolution of 1940 -was wholly contingent on the domestic repercussions of unpredictable external events; it was an accident of history with no 'social-evolutionary origins' in the interwar decades:

many people simply changed their minds as to how the world should be run and who should run it. They did so because the premises upon which they based their political judgements were suddenly falsified, or appeared to be falsified, by the events of May 1940: the fall of Chamberlain and the rise of Churchill, whose rise also meant the rise of Labour. ${ }^{13}$

This reading of 1940 as historical accident reinforces McKibbin's subsequent analysis of the brittle character of Labour's post-war social democracy, which went some way towards economic redistribution but left Britain's social and political institutions decidedly undemocratized. As in Classes and cultures, McKibbin emphasizes continuity across the interwar, war and post-war periods; Britain was 'recognizably the same country' in 1951 when the Conservative party returned to office. ${ }^{4}$ Social hierarchies were intact and the electorate remained 'ideologically and personally attached to the institutional status quo'. ${ }^{15}$ Again, the explanation for this continuity lies in the absence of any real or substantive 'democratization' of social and political structures after 1918, the year in which the working class controlled more votes than all other social groups put together. Despite this unprecedented transfer of political power, for McKibbin, Britain's democracy between the wars remained rooted in social hierarchy, cultural privilege and the continuing centrality of 'semi-feudal' civil and political institutions.

\section{I}

Classes and cultures and Parties and people together represent an extraordinarily rich contribution to historical understanding. They offer compelling answers to

\footnotetext{
${ }_{13}$ McKibbin, Parties and people, p. $180 . \quad{ }^{14}$ Ibid., p. $193 . \quad{ }^{15}$ Ibid., p. 200.
} 
the old problem of explaining electoral change whilst positing a highly nuanced and suggestive argument about the character of democratic society which resonates in a wholly different analytical register. The two books provide, as one colleague and admirer has remarked of McKibbin's earlier work, 'a complete statement of a historian's perspective and of a historical world' ${ }^{16}$ Reflecting its origins in the Ford lectures of 2008, Parties and people in particular presents its interpretation with breathtaking analytical unity; it provides, in McKibbin's own words, 'an argument within which England's political history as a whole can be contained'. ${ }^{17}$

'Can', that is, but need not necessarily. Naturally, such a significant contribution is bound to provoke argument and debate, and whilst McKibbin's account of interwar political culture has been undoubtedly influential, little of the growing body of recent work on this broad theme would concur with its every conclusion. Indeed, on closer inspection, what this wider literature reveals is the multiplicity of ways in which the character of Britain's democratic society between the wars might be assessed.

Before investigating these alternative possibilities, it makes sense to address specific points of contention in McKibbin's narrative. Arguably, the most obvious of these is the claim that Labour's landslide election victory in 1945 was wholly contingent on the events of May 1940 and had no ideological underpinnings in the earlier period. This claim sits uneasily alongside both established accounts and more recent work which shows how Labour made extensive efforts to meet the anti-socialist challenge between the wars by refashioning its identity as an inclusive and progressive coalition representing the interests of all workers, from the unpaid housewife to the salaried manager. Laura Beers's exploration of Labour's relationship with the media, for example, shows how party leaders gradually came to embrace new forms of mass communication and advertising techniques in order to project an appealing image of moderate, reformist politics to a broad cross-section of the electorate. The 1945 victory cannot be adequately explained, Beers persuasively argues, without consideration of how Labour learned to speak to a mass democracy through its encounter with the mass media after $1918 .^{18}$ In a similar vein, Jon Lawrence argues that interwar Labour politicians made significant advances in broadening their party's appeal beyond the traditional industrial heartlands; this task involved disavowing 'vernacular languages of class rooted in the supposed opposition between manual and non-manual labour', and constructing instead 'an alternative, more inclusive politics intended to transcend the visceral tensions of class feeling'. ${ }^{19}$ This determination to resist Conservative caricatures of Labour as the champion of sectional interests at odds with the

${ }^{16}$ Ghosh, 'The Guv'nor', p. 15.

${ }^{17}$ McKibbin, Parties and people, p. viii.

18 Laura Beers, Your Britain: media and the making of the Labour party (Cambridge, MA, 2010).

19 Jon Lawrence, 'Labour and the politics of class', in David Feldman and Jon Lawrence, eds., Structures and transformations in modern British history (Cambridge, 201 1), p. 239. 
constitution, Lawrence contends, was crucial to the party's breakthrough in May 1940. Indeed, the negotiations through which Labour joined the wartime coalition could hardly have been concluded so swiftly and with so little public controversy had the party not proved its willingness to govern in the 'national' interest in the preceding years.

In this light, the events of May 1940 and election result of 1945 appear rather less contingent and rather more rooted in political developments after 1918 . Recent studies of Labour party 'cultures' and 'identities' between the wars have added to this more nuanced and multifaceted picture of a party striving to broaden and deepen its electoral appeal. ${ }^{20}$ How far those efforts were rewarded with concrete electoral success before 1940 is, of course, rather more doubtful; Labour won its highest-ever share of the vote ( $3^{8}$ per cent) at the general election of 1935 and doubled its individual party membership between 1928 and 1937 , but came away from the election with only 154 seats and had made only limited inroads at municipal level by the close of the decade. ${ }^{21}$ Yet even were one to accept that the National Government's electoral position was unassailable on the eve of the Second World War, one must ask whether it need necessarily follow, as it does for McKibbin, that Britain's political culture had therefore undergone little, if any, democratization. To pose this question is to expose the core assumption running throughout Parties and people (and, by implication, Classes and cultures), namely, that a truly 'democratized' political culture is one in which Labour governs. For McKibbin, the latter is not merely an indication of the former, but an essential precondition (although by no means a guarantee).

Now, in so far as Labour was the party of the organized working class throughout the period in question, this assumption is correct. Yet to equate Labour with 'democracy', or, more precisely, to judge the 'democratic' character of British society by the criterion of an unrealized post-war social democracy, may fit with McKibbin's own ideological world-view, but it closes down alternative interpretative possibilities. To take one example, Parties and people acknowledges the existence of a substantial 'middle opinion' in the 1930 s committed to pursuing a 'third way' between state socialism and unfettered market capitalism, together with the large memberships of such bodies as the League of Nations Union (LNU), the Left Book Club, and the Aid to Spain movement, which coalesced around opposition to the National Government's foreign policy in the later 193os. It even concedes that such bodies might be evidence that 'something was happening' to radicalize public opinion in these years. ${ }^{22}$ Yet the salient fact for McKibbin

20 Matthew Worley, ed., The foundations of the British Labour party: identities, cultures and perspectives, I900-1939 (Farnham, 2009); Matthew Worley, ed., Labour's grass roots: essays on the activities of local Labour parties and members, I9I 8-I945 (Aldershot, 2005).

${ }^{21}$ Andrew Thorpe, A history of the British Labour party (3rd edn, Basingstoke, 20o8).

22 McKibbin, Parties and people, p. 107. 
remains that such opinion did not translate into sustained electoral support for Labour before May 1940. This may, of course, be true, but it is a problematic conclusion in the sense that it closes down rather than opens up debate on the possible significance of these movements for Britain's interwar democracy.

The size and reach of the LNU, for instance, demonstrates the success with which liberal internationalists promulgated their ideas to a mass electorate, whilst its famous 'Peace Ballot' of 1934-5 (in which almost 12 million people participated) indicates the considerable potential for popular mobilization over matters of foreign policy. ${ }^{23}$ This rather flies in the face of McKibbin's claim that foreign affairs were electorally marginal during the period. As Susan Pedersen points out in her perceptive review of Parties and people, not only did politicians believe credibility on international issues to be important, but packed into the centrist appeal of the Baldwinite Conservative party was an important set of assumptions about Britain's status as an enlightened liberal-imperialist power and a major force for international conciliation. ${ }^{24}$ It is difficult to explain why the party spent (some might say, wasted) so much time appeasing the LNU in order to burnish its own liberal internationalist credentials if doing so served no electoral purpose. ${ }^{25}$

More generally, the presence of mass pressure groups like the LNU, as well as the less overtly political voluntary organizations which flourished between the wars, suggests that civil society was very obviously undergoing a process of democratization following the introduction of universal suffrage. Although reliable and comparative data is elusive, the weight of evidence suggests that more British people participated actively in voluntary organizations after the First World War than had before. Not only did membership of political parties grow dramatically, but 'non-party' organizations, from the National Council of Women and the Women's Institutes to the British Legion and Rotary International, occupied an increasingly prominent place in civic associational life, combining social and educational work with the pleasures of organized sociability. Added to these-and falling more squarely in the recreational bracket-were the ballooning membership of the Club and Institute Union (918,ooo in 1929), the million or so boys and girls who joined the Scouts and Girl Guides during the period, and the countless thousands who belonged to church-based organizations, sports clubs, orchestras, choirs, and amateur dramatics societies. ${ }^{26}$

${ }^{23}$ Helen McCarthy, 'Democratizing foreign policy: rethinking the Peace Ballot, 19341935', Journal of British Studies, 49 (2010), pp. 358-87.

${ }^{24}$ Susan Pedersen, contribution to round-table on Parties and people in Twentieth Century British History, 21 (2010), pp. $5^{61-4}$.

${ }^{25}$ An argument developed in Helen McCarthy, The British people and the League of Nations: democracy, citizenship and internationalism, c. I9I8-I945 (Manchester, 2011).

${ }^{26}$ See Helen McCarthy, 'Associational voluntarism in interwar Britain', in Matthew Hilton and James McKay, eds., The ages of voluntarism: how we got to the Big Society (Oxford, 2011), pp. $47-68$. 
Classes and cultures suggests that these associational habits served to depoliticize civic life, with middle-class organizations in particular avoiding 'political' talk, a tendency which reinforced the discursive identification of Conservatism with the 'public' interest. As this reviewer has argued, this depoliticized associational culture can be read differently, less as an instinctive facet of middle-class anti-socialism and more as a considered strategy for bridging partisan and sectarian divides in civil society. ${ }^{27}$ Frequently, the bar fell on divisive partisan behaviours, rather than on 'political' talk per se, and was intended to facilitate rather than inhibit public debate. Indeed, the sheer number of places in which British people could meet to discuss public affairs between the wars casts serious doubt upon the rather extraordinary claim in Parties and people that large numbers of voters 'freely abdicated any active political role or judgement in favour of elites who were still largely Edwardian'. ${ }^{28}$ Even discounting the serious-minded and highly vocal public associated with 'middle opinion' and anti-fascism in the later 193 os (which was sizable), this conclusion seems implausible, and it appears even more so when one considers the extensive political education campaigns inspired by the introduction of universal suffrage. Parties and non-party organizations alike sought to foster intelligent, responsible citizenship amongst the mass electorate, by promoting the study of domestic or foreign affairs, training up public speakers and organizers, encouraging members to stand for election to municipal bodies, and emphasizing more generally the importance of independent critical thought, particularly when consuming news and information from an increasingly sensationalist mass media. ${ }^{29}$

Naturally, these efforts frequently fell on deaf ears; for many, perhaps for most, the appeal of a political meeting or an improving public lecture was easily trumped by the lure of the cinema or dancehall, or even the prospect of a night in with the wireless. However, it should not be assumed that the effect of commercialized leisure, which gathered apace between the wars, was always to de-politicize. James Nott has suggested that, despite their uses for escapist entertainment, radio (including the more commercial end), newsreels, and mass circulation newspapers served to make the interwar generation 'better informed than virtually all who had preceded it'. ${ }^{30}$ This was confirmed in the behaviours of politicians, who frequently assumed that voters were better informed, or were, at the very least, capable of responding to rational argument.

\footnotetext{
${ }^{27}$ Helen McCarthy, 'Parties, voluntary societies and democratic politics in interwar Britain', Historical Journal, 5o (2007), pp. 891-912. $\quad{ }^{28}$ McKibbin, Parties and people, p. 195.

${ }^{29}$ For the Conservative party, see E. H. H. Green, Ideologies of Conservatism: conservative political ideas in the twentieth century (Oxford, 2002), ch. 5; for Labour, Stuart Ball, Andrew Thorpe, and Matthew Worley, 'Elections, leaflets and whist drives: constituency party members in Britain between the wars', in Worley, ed., Labour's grass roots, pp. 7-32. For non-party organizations, see McCarthy, 'Associational voluntarism.'

$3^{\circ}$ James J. Nott, Music for the people: popular music and dance in interwar Britain (Oxford, 2002), p. 228.
} 
As Jon Lawrence has shown, politicians across all three main parties largely abandoned the crude, fiercely partisan propagandizing which had characterized electoral politics before 1914 in favour of more sober and restrained tactics, convinced that the mass electorate, containing as it did a large, unaligned 'silent majority', would respond more positively to calm, reasoned appeals, frequently in the form of the written word. Shunning Edwardian-style 'stunts' and physical confrontation, Lawrence argues, most interwar politicians sought to 'substitute a deliberative for a demonstrative model of citizenship'. $3^{1}$

Such a model was viewed as especially attractive to the new female electorate, large numbers of whom flocked to join Women's Institutes, Townswomen's Guilds, and Women's Citizens Associations, as well as the women's sections of the main political parties and mixed organizations like the LNU. As Pat Thane, Caitriona Beaumont, and others have shown, these bodies actively encouraged female voters to reflect upon their collective political power and civic responsibilities and to channel their energies into constructive public work. ${ }^{2}$ While many of these organizations explicitly disavowed any 'feminist' identity, preferring to talk in terms of 'service' or 'good citizenship', it is virtually unarguable that their overall effect was to extend the scope of women's participation in public life and to force issues affecting women (including more obviously 'feminist' demands such as equal pay) up the legislative agenda. Furthermore, this period witnessed the emergence of a range of smaller singleissue groups, such as the National Council for the Unmarried Mother and her Child, the Abortion Law Reform Association, and the Over Thirty Association (which campaigned for better housing and financial security for older unmarried women). 33 Although their core demands would not be met until after the Second World War (or even later), the mere existence of such bodies prove that opportunities for political self-expression greatly multiplied for women after their enfranchisement.

The extent to which the working classes were better represented within the institutions of civil society between the wars is less clear. Staying in the

${ }^{11}$ Jon Lawrence, Electing our masters: the hustings in British politics from Hogarth to Blair (Oxford, 2009), p. 128.

$3^{2}$ Pat Thane, 'What difference did the vote make?', in Amanda Vickery, ed., Women, privilege and power: British politics, I 75 o to the present (Stanford, CA, 2001), pp. 253-88. See also Caitriona Beaumont, 'The women's movement, politics and citizenship, 1918-1950s' in Ina ZweinigerBargielowska, ed., Women in twentieth-century Britain (Harlow, 2001), pp. 262-77.

33 Pat Thane, 'Unmarried motherhood in twentieth-century England', Women's History Review, 20 (2011), pp. 11-29; Stephen Brooke, “"A new world for women”? Abortion law reform in Britain during the 1930s', American Historical Review, 106 (2001), pp. 431-59; for Over Thirty Association, see Kath Holden, The shadow of marriage: singleness in England, I9 I4I96o (Manchester, 2007), pp. 25, 33-4. One might add to this list the National Spinsters' Pension Association, a largely working-class organization founded in 1935 to demand that never-married women receive state pensions at fifty-five rather than sixty-five, as was the case for widows (Holden, Shadow of marriage, pp. 34-5). They won a partial victory in 1940, when the government reduced the retirement age for all women to sixty. 
associational realm, many of the largest voluntary associations (outside the labour and trade union movement) were nominally cross-class in character, but, as in earlier periods, the middle classes tended to monopolize positions of leadership thanks to the greater time, money, and other resources at their disposal.34 Some associations, particularly those with a charitable or educational remit, remained highly paternalistic. Yet this paternalism could not simply go on as it always had, oblivious to the more expansive conception of social rights taking form after 1918. To take one example from the recent literature: in her wide-ranging study of 'life reform' and physical culture movements in modern Britain, Ina Zweiniger-Bargielowska points to an explosion in voluntary organizations promoting healthy living to the urban masses in the 1920 in response to public anxiety about the ' $\mathrm{C}_{3}$ ' physical status of an 'Al' nation. 35 The People's League of Health, the Sunlight League, and the New Health Society all presented the cultivation of good health as a civic duty rather than the object of welfare policy, which, for Zweiniger-Bargielowska, places health campaigns firmly on the right of the political spectrum; they combined 'an embrace of modern science and technology with a conservative, paternalist ideology'. ${ }^{6}$ Yet these campaigns took place in the context of higher public spending on social services, which more than doubled between the wars, marking, in Zweiniger-Bargielowska's words, 'the transition between the New Poor Law's ethos of less eligibility and the comprehensive welfare state established after 1945'.37 Good health might, then, require self-discipline and sound personal habits amongst the working classes, but it would also be secured by state intervention (albeit of a patchy and uneven nature) through an expansion in health visiting, infant welfare centres, and antenatal clinics; through the provision by local authorities of more playing fields and open spaces; and through the extension of paid holidays to increasing numbers of manual workers. $3^{8}$

For the National Government, under which most of these reforms took place, such interventions were patently not designed to serve social-democratic ends. They were (as McKibbin would undoubtedly agree) a product of liberal Baldwinite Conservatism, designed to ameliorate the worst excesses of industrial capitalism, preserve social stability, and make socialism (or worse) appear unnecessary. Yet intentions and effects in history are very different things. The interwar debate concerning paid holidays for manual workers is a case in point. As Sandra Dawson has recently shown, advocates of a statutory entitlement to

\footnotetext{
34 A good example is amateur operatics. See John Lowerson, Amateur operatics: a social and cultural history (Manchester, 2005).

35 Ina Zweiniger-Bargielowska, Managing the body: beauty, health and fitness in Britain, I $880-$ I939 (Oxford, 2010).

$3^{6}$ Ibid., p. 192.

$3^{8}$ For a general overview of healthcare policy between the wars, see Virginia Berridge, 'Health and medicine', in F. M. L. Thompson, ed., The Cambridge social history of Britain, I750I950, III: Social agencies and institutions (Cambridge, 1990), especially pp. 226-35.
} 
paid holidays for all presented this demand as a 'symbol of social as well as political citizenship'.39 The worker, they argued, and his wife who laboured just as hard every day in the home, had as much right to leisure as their salaried counterparts, who typically received one or two weeks paid vacation each year. To perpetuate this inequality, they argued, was to endorse a two-tier system in which the manual worker's labour was valued less than that of the black-coated worker. Although the legislation which resulted from this campaign-the Holidays with Pay Act of 1938-stopped short of mandating a week's annual paid vacation to all full-time workers, it indicated a shift in public policy which now sought actively, in Dawson's words, to 'democratize leisure'. $4^{\mathrm{o}}$ The act triggered a flurry of activity by municipal authorities, trade unions, and entrepreneurs to create the mass holiday industry required to cater for millions of newly leisured working-class families. Regardless of the ideological complexion of the government that introduced it, it seems clear that the 1938 act thus served to legitimize a social-democratic understanding of the individual's 'right' to leisure.

The force of the holidays with pay campaign was bolstered by debates about poverty, unemployment, and malnutrition, issues captured and ritualized in the hunger marches of the 193 os which, James Vernon argues, served to 'invert the logic of welfare by claiming it as part of the commons, a social right'.$^{\mathbf{1}}$ Furthermore, the centrality of the figure of the careworn housewife to the campaign reinforced feminist arguments for greater public recognition of women's unpaid labour, in the form of taxpayer-funded family allowances and improvements to the design and physical condition of the homes in which the bulk of that labour was performed. Although feminists had to wait until 1945 for the introduction of family allowances, many women benefited between the wars from the expansion of modernized housing estates, municipal investment in electricity, hot water supply and communal washing facilities, and government efforts to control food prices in recognition of the impact on female consumers. ${ }^{2}$ Whilst Labour women were particularly prominent advocates of these reforms, the campaign for labour-saving technologies in the home stretched to non-party organizations such as the Women's Institutes and Soroptimist International, as well as such middle-class feminists as Caroline Haslett. Working through the Electrical Association for Women, Haslett pushed for women's representation on municipal housing and electricity committees and urged manufacturers to listen carefully to the needs and preferences of

39 Sandra Dawson, 'Working-class consumers and the campaign for holidays with pay', Twentieth Century British History, 18 (2007), p. 282.

$4^{\mathrm{o}}$ Ibid., p. 303 . See also discussion of Labour's promotion of facilities for open-air bathing and sunbathing after 1929, in Zweiniger-Bargielowska, Managing the body, pp. 294, 297-8.

$4^{1}$ James Vernon, Hunger: a modern history (Cambridge, MA, 2007), p. 238.

$4^{2}$ Pamela M. Graves, Labour women: women in British working-class politics, I9I8-I939 (Cambridge, 1994); Thane, 'What difference'; Matthew Hilton, 'The female consumer and the politics of consumption in twentieth-century Britain', Historical Journal, 45 (2002), pp. 103-28. 
housewives when designing appliances for the home.43 These initiatives could justifiably be criticized for reinforcing the traditional ideology of the male breadwinner, but they nonetheless played an important role in elevating women's unpaid work in the home to the same status as paid work outside the home, and insisting upon the housewife's equal right to leisure.

\section{I I}

All this would suggest that the redistribution of 'social esteem', which McKibbin argues resulted from the peculiar conditions of the Second World War, was already well underway in the interwar years. This was not social democracy, at least not in the sense that McKibbin recognizes it; but it was a form of 'democratization' which reached far beyond formal political citizenship. Indeed, when one probes deeper into the social and cultural history of the period, one finds a democratizing impulse seemingly everywhere: the democratization of writing; 44 of music; 45 of fashion; $4^{6}$ of marital relations; 47 of selfhood and the emotions. $4^{8}$ Exactly how such processes related to the development of political democracy is not always spelled out in these studies; frequently the democratizing agent is identified as American-style consumer capitalism allied with new technologies of mass communication, rather than the passage of franchise reform legislation. These phenomena, it might be noted, were equally present in non-democratic societies such as Germany in the 1930s. 49

And yet these broader transformations clearly were connected to political democracy as it developed in industrial-capitalist societies from the later nineteenth century. Just as industrialization, urbanization, and growing literacy created the conditions and demand for popular government in Britain, so did the widening franchise reconfigure the meanings attached to work, leisure, and cultural consumption. As Brad Beaven has shown, debates

43 Suzette Worden, 'Powerful women: electricity in the home, 1919-1940', in Judy Attfield and Pat Kirkham, eds., A view from the interior: women and design (London, 1989), pp. 131-50.

44 Chris Hilliard, To exercise our talents: the democratization of writing in Britain (Cambridge, MA, 2006).

45 Nott, Music for the people.

$4^{6}$ George Orwell and J. B. Priestley both reflected on the levelling effects of cheap, massproduced clothes, particularly for women. See George Orwell, 'The lion and the unicorn', in George Orwell: Essays (London, 2000; orig. publ. 1940), pp. 157-8; J. B. Priestley, English journey (London, 1934), p. 401. See also Sally Alexander's discussion of the significance of dress in 'Becoming a woman in London in the 1920 and '3os', in Becoming a woman and other essays in nineteenth- and twentieth-century feminist history (London, 1994), pp. 203-24.

47 Marcus Collins, Modern love: an intimate history of men and women in twentieth-century Britain (London, 2003); Jane Lewis, The end of marriage? Individualism and intimate relations (Cheltenham, 2001); Alison Light, Forever England: femininity, literature and conservatism between the wars (London, 1991).

$4^{8}$ James Hinton, Nine wartime lives: Mass Observation and the making of the modern self (Oxford, $2010)$.

49 Victoria de Grazia, Irresistible empire: America's advance through twentieth-century Europe (Cambridge, MA, 2005). 
concerning the 'problem' of working-class male leisure were, from the midnineteenth century, intimately bound up with questions of citizenship; the passage of the 1867 Reform Act, which enfranchised the urban male artisan, only intensified these debates, in which the development of appropriate leisure forms - whether by moralizing philanthropists or profit-hungry entrepreneurs was viewed as crucial to the task of integrating new working-class voters into the political nation. $5^{\circ}$ As the rights of citizenship gradually expanded through franchise extensions and welfare reform, Zweiniger-Bargielowska argues, so did its responsibilities, which, by the turn of the century, came to encompass the civic duty of physical health. $5^{1}$ This duty was initially framed in genderdifferentiated terms, with the fit male body of the worker-soldier complemented by women's reproductive work as mothers of the race; yet first-wave feminists reconfigured the physical culture ideal by challenging medical discourses of feminine frailty, laying claim to leisure facilities and urging women to adopt more active lifestyles. By the 1930s, women's opportunities for physical outdoor pursuits had been transformed through the new practices of mixed bathing, sunbathing, hiking, and 'keep-fit' groups, thus demonstrating the link between political and social citizenship. This link was also personified by the broadcasters, journalists, intellectuals, and artists who pioneered new cultural forms after 1918 designed to educate and uplift the mass electorate, from BBC talks and the documentary film movement to modernist art on the London Underground..$^{2}$ Finally, it was unmistakable in the rise of the popular press, which flourished between the wars as daily newspaper reading became a normal feature of working-class life, playing a crucial role in fostering a sense of belonging to a national political community. 53

Even if similar 'mass' cultural forms existed under Fascist regimes, they remained the product of democratic impulses, only now appropriated by and subordinated to Fascist ideology. This was the view taken by the philosopher Karl Mannheim in 1933, who argued that the rise of the dictators only confirmed the recent trend towards 'an ever fuller development of democratic patterns of thought and behaviour,' for Fascism was but a response to the problems of democracy. 54 For Mannheim, democracy was a tendency not confined to the political sphere; the core democratic principles that every human being was equal, autonomous, and shared the responsibilities of

\footnotetext{
$5^{\circ}$ Brad Beaven, Leisure, citizenship and working-class men in Britain, I850-1945 (Manchester, 2005). $\quad 5^{1}$ Zweinigner-Bargielowska, Managing the body, p. 13.

$5^{2}$ DL LeMahieu, A culture for democracy: mass communication and the cultivated mind in Britain between the wars (Oxford, 1988). See also Scott Anthony, Public relations and the making of modern Britain (Manchester, forthcoming 2012).

53 Adrian Bingham, Family newspapers: sex, private life and the British popular press, $1918-1978$ (Oxford, 2009).

${ }^{54}$ Karl Mannheim, Essays on the sociology of culture: collected works, VII (London, 1997; orig. publ. 1956), p. 171.
} 
determining public policy implied 'a basic attitude which reaches beyond politics proper and shapes all cultural manifestations of societies of the democratic type'. 55 It seems undeniable that such an attitude was present and on the rise in interwar Britain; the question for the historian, one might say, is just how prevalent was this attitude and how far did it transform British politics and society?

Classes and cultures and Parties and people offer one set of answers; other studies, as this review has sought to show, point to different conclusions, and there will undoubtedly be further answers to come. There is still much we do not know about the character of Britain's interwar democracy. The role of local government as an arena for participation by under-represented groups, especially women, is seriously under-researched. Even though historians now have the benefit of the rich empirical base supplied by Sam Davies and Bob Morley's comparative analyses of county borough elections, we still have no systematic knowledge of what kinds of people stood for election to municipal office and whether opportunities to do so were distributed more widely after $1918.5^{6}$ We also know very little about how relations between MPs and constituents outside elections were reshaped between the wars. As Philip Cambray noted in his 1932 study, The game of politics, this was the period in which parliament became a destination for the domestic tourist, whose holiday programme would include 'attendance at a Debate if possible, a call on one's Member if the House is in session, or, at least, a visit during the hours Westminster Palace is open to the public'.57 It was also the era of the first MP's surgery, which appeared in 1924 when politicians became entitled to free rail travel between their constituencies and Westminster. Jon Lawrence is undoubtedly right to suggest that the early adopters of this novel form of voter-engagement were motivated by a desire to "shore up the local bases of politics in an age when impersonal, national forces appeared to hold greater and greater sway' $5^{8}$ Yet there is much scope for exploring in greater detail how far these efforts bore fruit, together with the broader and evolving role of MPs (paid since 1911) in servicing their constituencies: what difference did the transition to mass democracy make to the range and volume of issues that politicians were confronted with in their constituency postbag each week? Did

\footnotetext{
55 Ibid., p. 176 .

$5^{6}$ Sam Davies and Bob Morley, County borough elections in England and Wales, I919-1938: a comparative analysis: I: Barnsley-Bournemouth (Aldershot, 1999), II: Bradford-Carlisle (Aldershot, 2000), III: Chester-East Ham (Aldershot, 2006). Much of the existing literature tends to focus more narrowly on the development of political parties, for example, Michael Savage, The dynamics of working-class politics: the Labour movement in Preston, I880-I940 (Cambridge, 1987); Karen Hunt, 'Making politics in local communities: Labour women in interwar Manchester', in Worley, Labour's grass roots, pp. 79-101.

57 Philip Cambray, The game of politics: a study of the principles of British political strategy (London, 1932), pp. 123-4.

$5^{8}$ Lawrence, Electing our masters, p. 118.
} 
voters make more demands on their representatives? Were those demands more varied or expansive than in the past?59

There is scope, also, for further reflection on the ways in which political language was democratized following the passage of the Fourth Reform Act. Although often considered the terrain of the 'new' political history, it was McKibbin himself who drew attention to this dimension of interwar politics in The ideologies of class, in which he showed how skilfully the Conservative party discursively elided anti-socialism with defence of the 'public' interest. ${ }^{60}$ Philip Williamson's subsequent study of Stanley Baldwin's political leadership confirmed the crucial importance of public language in constructing Conservatism's electoral appeal, but his close reading of Baldwin's interwar speeches, writings, and broadcasts points to the emergence of a more inclusive and selfconsciously 'democratic' mode, which sought explicitly to 'reduce the distance between Conservative leadership and the new mass electorate'. ${ }^{61}$ The construction of imagined political communities after the 1918 and 1928 franchise extensions necessarily required lip service (at the very least) to be paid to the formal political equality of every member of the mass electorate; to do otherwise under conditions of universal suffrage had fatal electoral consequences, as Baldwin well understood. ${ }^{62}$ Yet whilst we are beginning to understand how this rhetorical commitment to democratic values played out in the public utterances of party leaders, there remains much work to do be done - on the discursive practices of the houses of parliament, local parties, non-party organizations, and the local and national press, for instance - before we can fully understand the formative role of political language in shaping interwar democracy.

Finally, and moving away from politicians and party activists, there remains the fundamental question of how much British voters knew or cared about domestic or international affairs. It is never difficult to assemble evidence of public 'apathy' or 'disengagement' in any period of history if one is determined to find it. To observe that the majority of Britons preferred dancehalls over debating clubs between the wars is to state the obvious; it is akin to noticing that the Fourth Reform Act did not produce an Athenian citizenry constantly engaged in lofty discussions of the affairs of the day. ${ }^{63}$ Well, how could it? But

59 Questions to which Richard Toye supplies some preliminary answers in 'The House of Commons in the aftermath of suffrage', paper given at the 'Aftermath of Suffrage' Conference, University of Sheffield, 24-5 June 2011.

6o McKibbin, 'Class and conventional wisdom: the Conservative party and the "Public" in inter-war Britain', in Ideologies of class, pp. 259-93.

61 Williamson, Stanley Baldwin, p. 106.

62 Roland Quinault notes that Baldwin's references to democracy as an MP before the First World War were 'few and unenthusiastic': Roland Quinault, British prime ministers and democracy: from Disraeli to Blair (London, 2011 ), p. 100.

63 See, for example, the unconvincing analysis in Kevin Jefferys's recent book, Politics and the people: A history of British democracy since I9I 8 (London, 2007), which concludes that Britain 'has never possessed anything that could be described as a 'vibrant' political culture and views political disengagement as a defining feature of British democracy throughout its history. 
what it did create were conditions of formal political equality, in which every citizen had, at the bare minimum, the opportunity to select those who ruled over them. With what resources did interwar Britons do so? How did they form their political views or develop their knowledge of public affairs? What respective weight, as historians, should we give to press, politicians and propagandists as opposed to family, friends and personal experience? Political scientists, and sociologists have provided answers to these questions over the years, but historians have held back, daunted perhaps by the considerable methodological challenges of reconstructing the political subjectivities of ordinary voters. Yet it is only by tackling such thorny problems, and uncovering new insights along the way, that we will gain a richer and more nuanced understanding of what democracy meant - and to whom it belonged - in Britain between the wars. 